\title{
사회적 기회 및 안전망 확대와 개발협력
}

\author{
김 성 규 (KOICA ODA연구실 상임연구원)
}

\section{목 차}

1. 문제의식: 왜 사회적 기회와 안전망인가?

2. 사회적 기회, 안전망 개념과 범위: 개도국 개발협력 맥락에서

3. 주요 이슈와 '좋은 사회적 안전망(Good Social Safety Net)'

4. 연구 방향과 범위제안

\section{1. 문제의식: 왜 사회적 기회와 안전망인가?}

인류의 경제적 성장지향에도 불구하고 해소되지 않고 있는 '지속적 위기(permanent crisis)1' 는 국가단위의 효과적인 사회보호 - 안전장치의 마련을 요구하고 있다. 특히 개도국 사 회가 사회 보장제도, 안전망 프로그램의 부재 속에서 경제위기, 사회 갈등과 같은 예상치 못한 내 · 외부 충격이 가해지면 단기적으로 그 사회는 위험상태로 빠질 수 있으며, 복구될 수 없는 상황에 이르게 될 수도 있다는 경험은 사회적 기회(Social Opportunity) 및 안전망(Social Safety Net) 구축의 중요함을 일깨워주고 있다.

1) 지속적 위기라 함은 그간의 극복 노력에도 불구하고 '구조화된 위기' 상황을 의미한다. 인류의 역사가 발전하고 경제적 성장 지향에도 불구하고 현재 지구상 총 인구의 $80 \%$ 가 사회적으로 안전하지 못한 상태(social insecurity)에 있으며, 삶의 주기에서 만날 수 있는 사회적 위험으로부터 충분히 보호받고 있지 못하다고 보고되고 있다(UNDP, ILO, 2011). 한편 World Bank 2011년 보고서에 따르면, 전 세계 약 14억 인구는 하루 1.25\$ 이하로 생활하고 있으며, 이들 대부분은 여성과 아동, 비공식 부문에 종사하는 노동자, 이주 노동자, 장애인, 질병감염·보 균자 들이다. 
실제로 1997년 중반 아시아 경제위기는 동 · 남아시아 개도국에게 큰 충격을 주었으며, '경제 성장이 사회발전을 위한 충분한 답이 아니라는 점' 과 '사회의 지속적인 발전을 이루기 위해서 는 불평등과 취약성 문제를 해결할 수 있는 공공정책이 추진되어야 한다' 는 문제의식을 가지기 시작했다. 또한 이들 국가들은 사회보호(Social Protection), 사회적 기회·안전망의 확대가 단기적인 경제위기에 대한 대응차원이 아닌 개도국의 '내적 성장 동력' 강화와 '사회통합' 증진 에도 기여할 수 있다는 점을 공유하였다.

더 나아가 사회적 기회 및 안전망의 확대는 부국과 빈국 간의 구조화된 불평등 해소와 국제적 재분배 기능을 활성화시키는 측면에서도 긍정적인 역할을 할 것으로 보고되고 있다. 이는 개발 협력 측면에서도 일방적, 단기적 개발원조가 빠질 수 있는 '악순환' 을 '선순환' 으로 전환시킬 수 있는 잠재력을 가진다는 점에서도 매우 중요한 의미를 지니고 있다.

한편, 국제기구와 선진 공여국도 MDGs 실현을 촉진하는 전략적 핵심 수단으로서 사회적 기 회와 안전망 확대 정책을 적극적으로 추진하였다. 이러한 노력은 빈곤의 문제를 단순히 경제적 차원에서 이해하는 것을 넘어 다양한 측면에서 이해하고 해결을 모색하려는 '빈곤의 다면성' 논의와도 이어진다. '빈곤은 단순한 경제적 궁핍이 아닌 빈곤층의 무력함과 배제를 의미 한다' 라는 경제학가 아마티아 센(Amartya Sen)의 정의도 이러한 맥락에서 이해될 수 있다. 결국 국 제기구와 선진 공여국은 사회적 기회와 안전망이 사회, 경제문제에 대한 사후적 대응뿐만 아니 라 위기가 발생하기 전의 사전적이고 예방적인 조치를 포함하는 다양한 정책 제도로 발전되기 를 희망하였다.

OECD DAC은 2001년 4월 채택한 가이드라인(the DAC Guidelines 2001: Povety Reduction)을 통해 식량, 에너지 문제, 기후변화 등 글로벌 차원에서 출현하는 다양한 위기 상 황과 도전 과제에 대한 대응을 강화하는 데 사회적 기회와 안전망 확대가 효과적인 도구로 작용 할 수 있음을 강조하였다. 서울 G20 정상회의도 '다년간 개발 행동계획(Multi-year Action Plan on Development)'을 통해 '경제위기 대응과 복원력 제고를 위해서는 사회안전망을 강 화해야 함' 을 중요하게 지적했다.

한국은 $\mathrm{OECD} \mathrm{DAC}$ 회원국으로서 이와 관련된 국제사회 논의에 적극 조응하며 개도국 사회 안전망 구축 지원에 대한 장기적 비전과 정책 방안을 모색할 의무가 높아지고 있다. 따라서 $\mathrm{KOICA}$ 입장에서도 이에 대한 보다 실천적인 반응과 지원 프로그램 모색이 필요한 상황이다.

이러한 배경 하에 본 글은 첫째, 개도국 개발협력 관점에서 사회적 기회 및 안전망에 대한 개 념 정의를 하고자 하며, 둘째 사회적 기회 및 안전망 확대를 위한 개발협력 방안과 관련하여 앞 으로의 연구 범위와 방향성을 제안해 보고자 한다. 


\section{2. 사회적 기회, 안전망 개념과 범위: 개도국 개발협력 맥락에서}

복지제도를 발달시켜온 선진국 맥락에서의 사회적 기회와 안전망은 '사회복지와 보험' 의 의 미에 보다 가깝다면 개도국 맥락에서의 그것은 보다 사회적 빈곤, 취약계층 보호(Protection) 의 의미로 해석되고 있다.

애초 사회안전망은 '국가 안보' 차원의 관심에서 출발했으며 이러한 맥락에서 개도국 개인의 복지와 안보는, 당시 확대되고 있었던 여러 위협요인들로부터 개인이 안전하게 지켜질 때 비로 소 그 의미를 가질 수 있다는 이른바 '인간안보(human security) $)^{2}$ '라는 개념과 연결되기도 했다.

이후 사회적 기회, 안전망에 대한 관점은 경제·사회위기 시 개인에 대한 사회보호(social protection)의 의미로 전환되었다. 실제로 사회적 기회와 사회 안전망이라는 용어가 보다 빈번 하게 회자되기 시작한 시기는 1997년 중반 동아시아 경제위기 이후이다. '사회 안전망' 이라는 용어 자체는 새로운 것이 아니었지만 당시 경제위기국면에서 이 개념은 새롭게 주목받고 회자 되기 시작했다.

일반적으로 사회적 기회는 '개인이나 집단이 목표를 성취할 수 있도록 사회가 허용하고 지원 하는 공식적인 제도의 총체' 로 이해될 수 있다. 이에 비해 사회적 안전망이라는 용어는 보다 포 괄적인 개념이라 할 수 있다3). 일반적으로 사회복지학계에서는 사회안전망을 사회보장제도와 같은 의미로 사용하기도 한다. 즉, 사회 안전망 개념을 사회보장제도가 갖는 사회적 안전장치로 서의 기능을 강조하는 차원에서 사용하거나, 사회보장제도의 범위에서 벗어나는 '예외적이며 돌발적인' 상황을 추가로 보호하는 기능을 주목하고 있다. 사회학계에서는 사회적 기회와 안전 망에 대한 보다 다면적인 접근을 시도하고 있는데, 안전망의 대상과 성격에 따라, 그리고 안전 망 관련 프로그램의 목표에 따라 그 성격과 기능을 달리 규정하고 있다. 즉 안전망의 대상을 특 정 보험의 가입자로 한정하는지, 보험 가입과는 무관한 일정 특징을 보이는 집단을 대상으로 하

2) '인간안보' 라는 개념은 1994년부터 유엔개발계획(UNDP)에서 본격적으로 사용되기 시작한 용어로, 개인의 안보란 국가의 외교관계나 대 외적인 군사적 힘 보다는 일상생활의 조건, 예를 들면, 식량 · 고용문제·건강 · 인권 · 공공 안전 등을 기준으로 평가되어야 한다는 주장을 담고 있다. 즉, 인간안보는 개인의 삶에 직접적인 영향을 미칠 수 있는 다양한 일상적인 위협요인들로부터 인간을 안전하게 보호할 때 확보될 수 있다는 것이다.

3) 개념적으로 사회적 기회와 안전망은 상호 독립적으로 사고할 수 없으며 현실적으로도 상호 보완적인 분석 기제로 작동된다. 예를 들어 관련 사회정책은 사회소외· 취약계층의 기본적 생활보호(사회적 안전망의 제공)를 목적으로 하는 동시에 정상적인 직업(사회)활동으로 복귀시키는 것(사회적 기회의 제공)을 목적으로 한다. 
는지에 따라, 그리고 프로그램이 경제위기 국면에서 지원을 목적으로 하는 단기일자리, 현금지 원 등 단기 프로그램인지 아니면 보다 중장기적인 교육, 보건, 의료 관련 프로그램 등인지에 따 라 안전망의 성격과 기능이 달라짐을 강조하고 있다.

개발정책 부문과 관련하여 사회적 기회 - 안전망의 범위와 내용을 살펴보는 것은 사회적 기 회, 안전망의 확대를 위한 개발협력 방안 모색이라는 측면에서 의미가 있는데, 이는 크게 평등 (equity), 사회적 위험관리(social risk management), 빈곤감소(poverty reduction), 사회 적 보호(social protection)의 네 영역으로 구분될 수 있다. 평등은 토지배분, 소유권과 계약의 시행, 기초교육 등의 관련 정책을 통해 달성하고자 하며, 사회적 위험관리는 취약 소농 지원, 농 업 진흥을 위한 관개사업, 취약계층 소액 대출, 기후정책 등을 통해 이루고자 한다. 또한 빈곤 감소 부문은 사회개발정책의 핵심 영역 중 하나인데, 성장에 빈곤층이 함께 참여할 수 있는 프 로그램을 모색하고 있다. 마지막으로 사회적 보호 영역은 노동정책, 사회보험, 사회 돌봄 서비 스 등을 그 내용으로 한다. 사회적 기회와 안전망은 이러한 네 영역 모두에 공통되고 바탕이 되 는 개념으로 이는 사회보험, 사회지원 그리고 통상적으로 교육과 의료부문을 포함하는 사회 서 비스 영역으로 구분될 수 있다.

한편, 사회적 기회와 안전망은 그 수준을 나누어 볼 수 있는데, 즉 〈그림 1〉에서 보는 바와 같 이 사회보험, 사회지원, 사회서비스 영역을 모두 포함하는 넓은 의미의 개념(사회 안전망 I)과 세 영역 관련 제도의 시행의 틈을 메꿔주는 좁은 의미로서의 개념(사회안전망 $\mathbb{I})$ 으로 구분해 볼 수 있다. 그런데 개도국 사회안전망에 대한 이해는 넓은 의미의 사회안전망 수준으로 접근하는 것이 각국의 안전망 제도의 전통과 방향성을 제시하는 틀의 설정 측면에서 보다 유용하다 하겠다.

\section{〈그림 1〉사회적 안전망의 수준}

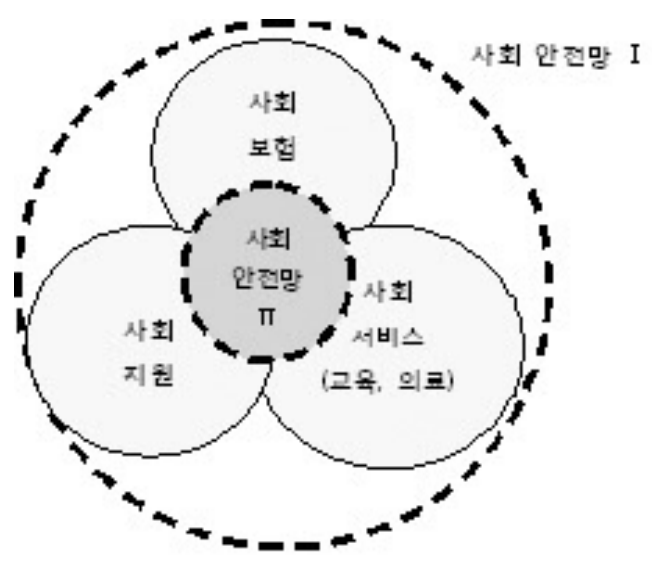


사회적 기회 및 안전망을 사회통합의 시각에서 볼 수도 있다. 한 사회가 통합을 이를 이루기 위한 방법에는 시장중심적인 접근과 국가 - 사회공동체 중심의 접근4)이 있으나 점차 후자의 시 각이 부각되었다. 사회적 기회와 안전망이라는 개념은 이러한 사회통합을 위해 국가 - 사회공동 체의 역할이 중요하다는 시각을 바탕으로 탄생했다. 결국 사회적 기회와 안전망은 사회통합에 적극적으로 기여하며, 이는 경제적 취약계층에 대한 자원분배기능, 사회적 불안정성 완화 기능 을 통해 달성될 수 있다고 보는 시각이다. 또한 초기의 사회안전망 개념은 사회복지의 '잔여적 기능 ‘, ' 잔여적 복지(residual welfare)' 와 동일시되었으나 80년대 이후 '경제적 희생집단' 에 대한 적극적 보호 수단을 사회안전망으로 지칭하게 되면서 보다 다면적이고 적극적인 의미를 함축하기 시작했다.

그런데 개도국 사회적 기회, 안전망의 구축과 적용에 있어 몇 가지 쟁점이 발생함을 알 수 있 다. 첫째, 어떤 위험에 대응하는 안전망인가 둘째, 안전망의 적용 대상과 그 범위 설정의 문제이 다. 셋째, 안전망 적용의 수준은 어느 정도로 설정되어야 하는가의 문제이다.

쟁점 별로 논의를 정리해 보면 다음과 같다. 첫째, 위험에 대한 규정은 나라마다 혹은 정치, 경제적 국면에 따라 상이하다. 이른바 복지 선진국들은 기본적으로 삶의 주기에서 발생할 수 있 는 '모든 위험' 으로부터 사회성원의 삶을 보호하기 위해 노력해 왔다. 그 결과 특정 소외, 저소 득 계층을 위한 안전망이 아닌 사회성원 모두가 노령, 질병, 사망, 실업, 출산 등으로부터 보편 적으로 보호받도록 노력 하고 있다. 반대로 개도국의 경우 안전망의 기본 개념은 존재하나 실제 적용에 있어 위험에 대한 규정은 협소하다. 우리나라의 경우도 사회안전망에 대한 중요성과 기 본 틀은 제시되고 있으나, 가족수당이나 출산수당 등 선진국에서는 보편화된 보장제도 조차 제 공되고 있지 못한 실정이다. 둘째, 안전망 적용대상과 범위에 대한 문제는, 우선 안전망 적용대 상을 특정계층에 한정지을 것인지 아니면 기본적으로 사회 구성원 모두를 포괄해야 되는지의 쟁점이 있다. 그리고 사회안전망의 적용 범위를 국가 - 사회수준, 집단수준, 개인 수준으로 구분 할 수 있는가의 문제가 있다. 일반적으로 관련 논자들은 사회안전망에 의한 보장이 개인의 소득 수준이나 사회 기여의 정도 등에 따라 일부 계층에게만 차등 적용된다면 그것은 오히려 안전망 으로서 기능하지 못하고 있다고 주장한다. 즉 사회 안전망은 그 범위를 보편적으로 적용해야 하

4) 시장 중심적 사고는 왜곡 없는 시장의 작동이야 말로 개인의 자유를 극대화하고 체계의 안정성을 보장할 수 있는 최선의 것이라고 생각하면서 시장의 자기평형(homeostasis) 기제가 사회통합의 핵심구조로 강조된다. 그러나 20 세기 후반의 세계사적 경험은 시장중심의 사회기제가 자기평형의 이름하에 경제적 빈부격차를 초래하여 구성원간 의 갈등을 심화시킴으로써 구성원 간에 자기 정체성을 제공한다는 의미에서의 사회통합에는 실패하였음을 보여주 었다. 국가 중심적 사고는 국가를 진보와 사회통합의 표방자로 간주하고 국가에 의한 시장의 계획화, 사회의 조직 화가 사회통합의 중심 기제라고 본다. 이는 서구의 복지국가체제로 구체화되었으며 시장의 실패를 국가 중심적인 보상기제를 통해 보완하려고 시도한다(박준후, 2000: 17-18). 
며, 특히 사회에서 소외되기 쉬운 저소득층을 안전망의 보호 범위에 포함시키는 것이 중요하다 는 주장이다. 이러한 문제의식을 가지고 접근할 때에만 사회안전망의 사각지대를 해소할 수 있 다고 본다. 셋째, 사회안전망을 통한 보호는 그 수준이 적절해야 한다는 점이다. 먼저 안전망 관 련 현금을 지급하는 경우 이것이 최저생계유지에 도움이 되어야 한다는 점, 그리고 재분배 효과 가 가장 극대화 될 수 있는 적정 수준을 찾는 것이 중요하다.

\section{3. 주요 이슈와 '좋은 사회적 안전망(Good Social Safety Net)'}

개도국 사회적 기회 및 안전망 구축과 관련해서 두 가지 논쟁적인 질문이 있다. 첫째는 그 목 적에 대한 질문인데, 즉 '성장인가, 빈곤감축인가' 이다. 두 번째는 개발협력 부문에 관한 질문 이다. 즉' 개도국의 경제 인프라 구축인가, 사회분야 지원인가?' 에 관한 질문이다.

먼저 '성장인가, 빈곤 감축인가' 에 대한 논쟁의 한 극단에는 국가단위의 경제성장 혜택은 빈 곤층과 사회취약계층에게 '자연스럽게' 흘러들어가며(trickle down), 따라서 경제성장만이 사 회적 기회, 안전망 구축에 전제가 될 수 있다는 성장 옹호론이 있다. 다른 한 극단에는 경제성장 은 아무런 의미가 없으며 오직 분배를 통해서만 사회 불평등과 사회 위험을 감소시킬 수 있다는 ‘복지국가 신봉론 혹은 복지만능주의론' 이 있다. 이러한 논쟁 중에 '경제성장이 빈곤과 사회 위 험의 감소를 위한 하나의 필요조건이지만 충분조건은 아니다' 라는 주장이 설득력을 지닌다. 특 히 개도국 발전의 '질과 수준' 이라는 문제에서는 이러한 점은 더욱 분명해 진다.

또한 '경제 인프라 구축인가, 사회분야 지원인가?' 에 관한 논쟁은 어떤 부문에 개발협력지원 을 하는 것이 개도국에 가장 효과적일 수 있는 것인가에 대한 논의이다. 이런 맥락에서 ‘수원국 의 정책과 사회시스템이 합리적이고 잘 갖춰져 있다면 공여국이 어떤 분야에 재정지원을 하는 지는 큰 문제가 되지 않을 수 있다' 는 견해는 결국 수원국 사회 분야 시스템 구축의 중요성을 강 조하는 주장으로 이어진다고 볼 수 있다.

이러한 맥락에서 개발협력과 개도국 사회적 기회와 안전망 확대 논의 관련 다음 몇 가지 점에 대해 생각해 볼 필요가 있다. 첫째, 사회적 기회 및 안전망 확대와 경제 성장과의 상관관계이다. 사회안전망의 구축과 적용은 '어느 정도' 의 경제적 수준을 전제로 한다는 견해가 있는데, 이는 '개도국은 사회보장이나 안전망을 실현할 '여유' 를 가지고 있지 못하며 따라서 개도국 사회안 전망 구축 논의는 시기상조' 라는 시각과 연관 있다. 이러한 시각은 서구의 발전된 복지, 사회 안 전망 시스템을 개도국 사회 안전망의 모델로 상정하고 있다. 그런데 Frota(2007) 등은 59개국 사례 연구를 통해 이러한 견해에 대한 반론을 제기하고 있다. 그 내용을 요약하면 첫째, 경제성 
장과 빈곤 감소는 상응하지 않는다는 점이다. 즉, 한 나라의 $\mathrm{GDP}$ 성장은 그 나라의 빈곤감소를 자동적으로 보장해주지 않는다. 둘째, 국가의 경제성장이 사회 정의(social justice)과 공정 (equity)을 보장하지는 않는다는 점이다. 즉 많은 나라들에서 경제성장과 무관하게 불평등과 불 공정은 증가하고 있다. 국제노동기구(ILO)도 기본적인 사회보장(basic social protection)에 대한 캠페인(Kulke, Ursula(2009)) 등을 통해 최빈 상태의 개도국이라 하더라도 그 사회 수준 에 맞는 최소한의 그리고 기본적인 사회보장(basic social protection)은 이루어져야 하며5) 오 히려 최빈 상태의 개도국에서의 사회안전망 구축은 더 시급하고 중요할 수 있다고 언급 한다6).

둘째, 사회적 안전망의 단기적 지원과 중장기적 지원 프로그램의 구별과 그 효과성에 대한 고 민이 필요하다. 예를 들어 경제위기와 재난 피해에 대한 빈민층, 사회취약계층 구호에는 단기 자금, 물품 지원이 필요하며 또한 높은 효과성을 가질 수 있으며, 개도국 빈곤감소와 사회정의 실현을 위한 사회 시스템 전환이라는 보다 장기적인 목표를 위해서는 단기적 자금 혹은 경제 인 프라 지원보다는 장기적인 '사회적 투자(social expenditure)' 가 보다 긍정적인 기여를 할 수 있다.

셋째, 개발협력 관련 개도국 사회적 기회, 안전망 확대 사업 부문을 부차적 결과물로 생각하 는 경향에 대해서이다. 예를 들어 $\mathrm{ODA}$ 사업의 활성화가 '궁극적' 으로는 사회적 기회나 안전망 확대에 기여한다는 접근방식이 그것인데, 이는 경계해야할 시각이다. 결국 개도국 사회적 기회, 안전망의 확대는 그 자체로 주요한 목표로 설정되어야 한다.

넷째, 개도국 사회적 기회 및 안전망 확대 관련 주체 설정의 문제이다. 이는 관련 프로그램이 성공적으로 이루어지기 위해서 사회안전망을 구축하고 구현하는 ‘주체’ 가 누가 되어야 하고 주 체들 간의 관계는 어떻게 설정되어야 하는가의 문제이다. 즉, 개발협력 사업에서 (1) 선진공여국 과 관련 국제기구의 역할, (2) 개도국 정부 혹은 시민단체 그리고 (3) 선진 공여국(혹은 국제기구)

5) 개도국 사회기회 · 안전망 확대는 1) 최소한의 기본적 보호 2) 정부와 민간섹터의 책임성 3) 인권을 기본적으로 고 려하며 4) 조직과 금융의 다원주의를 수용하며 5) Good tri-partite 와 financial governance 구축이 전제되어 야 한다(Luis Frota, 2007).

6) 개도국에서의 사회적 안전망이 오히려 더 중요한 이유는 다음 몇 가지로 정리될 수 있다. 첫째, 무엇보다 안전망 은 자연재해, 경제적 위기 등으로 야기된 일시적 사회 불평등 지수상승 혹은 극빈 상태 등에 즉각적이고도 단기적 인 처방을 하는데 매우 유효하다는 점이다. 둘째, 안전망은 가족, 가구 단위에 대한 단기적 현금 지원을 넘어 미래 를 위한 보다 나은 투자를 유도 한다는 점에서 의미가 있으며, 셋째, 안전망은 가구가 스스로 위험관리(risk management)를 할 수 있게 도와준다는 점이다. 
과 개도국 주체(정부 혹은 시민단체)간 역할관계 규정의 차원에서 고민되어져야 한다는 의미이다.

이러한 문제의식을 통해 이른바 ‘좋은 사회 안전망(Good Social Safety Net)이란 무엇인가 ‘에 대해 답해볼 수 있다. 결국 좋은 사회 안전망이란' 이상적으로 디자인되고 적용된 것' 이상 의 의미가 있다. 즉 안전망 프로그램이 그 사회의 공적 · 사회적 정책과 얼마나 잘 조응하는가에 따라 안전망을 평가할 수 있다. 첫째, 적절성(Appropriate)이다. 이는 정부의 장기 정책전략과 외부 환경을 고려하는 전제하에서, 디자인된 프로그램이 가장 시급한 사회 요구에 얼마나 반응 하고 이를 만족 시키는가의 문제이다. 두 번째 요소는 충분성(Adequate)인데, 이는 안전망 시 스템이 사회의 다양한 이해관계 그룹의 요구를 얼마나 조율, 지원하고 있는가의 문제이다. 예를 들어 빈곤이라는 사회 문제도 만성적 빈곤, 이행적 빈곤 문제 등 그 대상 설정에 따라 지원의 형 태와 내용이 다를 수 있기 때문이다.

〈표 1〉'Good Social Safety Net' 모델의 구성 요인과 효과성

\begin{tabular}{|c|c|}
\hline 구성 요인 & 효과성 \\
\hline 적절성(Appropriate) & 사회의 가장 시급한 요구에 민감하게 반응하고 이를 만족 \\
\hline 충분성(Adequate) & 사회의 다양한 이해관계 그룹의 요구를 합리적으로 조율, 지원 \\
\hline 공정성(equitable) & $\begin{array}{l}\text { 수평적 공정성(horizontal equity)과 수직적 공정성(vertical } \\
\text { equity) 달성 }\end{array}$ \\
\hline 비용효과성(cost-effective) & $\begin{array}{l}\text { 적절한 투입비용으로 프로그램의 분절성 극복, 시스템 기능을 } \\
\text { 극대화 }\end{array}$ \\
\hline $\begin{array}{l}\text { 동기부여 병행 } \\
\text { (incentive compatible) }\end{array}$ & $\begin{array}{l}\text { 프로그램이 수혜자의 동기부여와 긍정적인 부가 효과(positive } \\
\text { additional effect) 유발 }\end{array}$ \\
\hline 지속가능성(sustainable) & 수행 주체의 정책적 의지 공고화, 지속적 재정 지원 확보 \\
\hline 역동성(dynamic) & $\begin{array}{l}\text { 프로그램이 경제적, 사회적, 정책적인 변화에 맞춰 적응. 역동적 } \\
\text { 진화 }\end{array}$ \\
\hline
\end{tabular}

출처: 저자 정리, World Bank, 2008 참조

세 번째는 공정성(equitable)이다. 즉 사회적 안전망은 그 수혜대상자들에게 공정하고 형평성 에 맞게 다가가야 한다는 점이다. 이 원리는 개념적으로 수혜자들에게 같은 가치로 다가가야 한 다는 수평적 공정성(horizontal equity) 원리와 등급에 따라 수혜의 규모를 달리해야 되는 수 
직적 공정성(vertical equity) 원리로 다시 나눌 수 있다. 바람직한 사회적 안전망을 위한 네 번 째 요소는 비용효과성(cost-effective)을 꼽을 수 있다. 이는 프로그램의 경제적인 관리의 측면 인데, 프로그램의 분절성 극복, 시스템 기능을 극대화하고 목적을 달성하는데 투입되는 비용의 최소화를 의미한다. 다섯째, 동기부여가 병행(incentive compatible) 되는 안전망은 보다 바람 직하다고 할 수 있다. 이는 프로그램이 수혜자의 동기부여와 긍정적인 부가 효과를 유발시키는 것으로, 예를 들어 조건부현금이전(CCT) 프로그램은 단기적 현금, 현물 지원으로 그치는 것이 아니라 궁극적으로 빈곤 가구의 인적 자본 개발이라는 효과성을 기대하고 있다. 여섯째 요소는 지속가능성(sustainable)이다. 이는 좋은 안전망은 지속가능성이 높다는 것을 의미하며, 이는 수행 주체의 정책적 의지, 정부의 지속적 재정 지원 등으로 달성될 수 있다. 일곱째 요소는 역동 성(dynamic)이다. 즉, 좋은 안전망이란 경제적, 사회적, 정책적인 변화에 맞춰 이에 적응하고 새로운 문제를 해결해 나가는, 균형을 잃지 않으면서도 역동적으로 진화해 나가는 시스템이어 야 한다(Grosh, 2008).

그런데 언급한 바와 같이 사회적 기회, 안전망 모델은 그 자체로는 의미를 가질 수 없으며, 특 정한 사회와 환경의 요구에 얼마나 반응하고 이를 만족 시킬 수 있는가가 중요하다. 따라서 개 도국 상황에 맞는 사회적 기회, 안전망 확대 방안을 위해서는 관련 국제기구와 선진공여국의 대 개도국 지원 현황과 그 변화, 그리고 개도국 내의 사회적 기회, 안전망 구축 노력 자체에 대한 연구가 병행 될 필요가 있다.

\section{4. 연구 방향과 범위제안}

이상의 문제의식을 바탕으로 개발협력과 개도국 사회적 기회 및 안전망 확대와 관련, 주요 연 구 범위와 주제를 제시해 보면 다음과 같다. 이는 지금까지 개도국 사회적 기회 및 안전망 관련 주로 다뤄왔던 주제라기보다는 앞으로 보다 중요하게 탐구되어야할 영역으로 판단된다.

첫째, 개도국 사회적 일자리 확대 정책과 관련된 연구이다. 사회 안전망 관련 $\mathrm{EU}$, 미국 등 주 요 선진국 사회적 기업, 일자리 정책과 사례연구가 진행되었으나 개도국 사회적 기회와 안전망 확대 차원의 사례연구나 모델 연구는 충분히 수행되고 있지 못하다고 판단된다. 따라서 개도국 일자리 정책 관련 중요 주제와 사례선정(targeting), 사례조사(case study) 그리고 유형분석 (trend analysis)은 연구 영역측면에서 뿐만 아니라 사업실행 측면에서도 의미하는 바가 크다 할 것이다. 일자리 창출 사업은 개도국의 사회적 기회와 안전망을 동시에 충족시킬 수 있는 프 로그램으로, 특히 개도국 빈곤층에게 '자력구제안전망' 을 제공하는 효과를 가질 수 있다고 평 
가된다. 연구 가설은 '사회서비스 혹은 사회적 일자리 확대와 이를 통한 사회적 경제(social economy) 영역의 확대는 개도국 취업계층에 대한 빈곤탈출 가능성을 높임과 동시에 빈곤에 대 한 안전망을 제공할 수 있다 로 설정될 수 있다. 이는 일시적 현금 지원 프로젝트에 비해 안정 적이고 지속 가능한 일자리를 제공할 수 있으며, 결국 사회적 일자리가 취약계층의 재빈곤화 위 험성을 방지하는 기제로 작동할 수 있다는데 그 초점이 맞춰져 있다. 또한 사회적 일자리 확대 는 새로운 영역에서의 일자리 창출을 의미하며, 따라서 단순하고 불안정한 일자리가 아닌 차별 성과 전문성을 담보하는 '괜찮은 일자리(decent work)' 창출로 이어질 가능성이 높다는데 주 목한다.

\section{〈표 2〉개도국 사회적 기회. 안전망 관련 주요 연구 범위와 대상}

\begin{tabular}{l|l}
\hline \multicolumn{1}{c|}{ 연구 주제와 범위 } & \multicolumn{1}{c}{ 연구 대상 } \\
\hline 개도국 사회적 일자리 확대 정책 & $\begin{array}{l}\text { 일자리 창출 사업과 기업의 사회적 책임 } \\
\text { (CSR) 연계/ Global CSR } \\
\text { 괜찮은 일자리(Decent Work) 확대 방안 } \\
\text { 노동복지(Workfare) 프로그램 }\end{array}$ \\
\hline 개발협력에서의 민간부문 활성화 방안 & $\begin{array}{l}\text { 공공-민간 파트너십(PPP) 구축과 사회적 } \\
\text { 기회 안전망 환대 } \\
\text { PPP 구축 성공사례 발굴 및 모델링 }\end{array}$ \\
\hline 수원국 중신 인적자원개발 지원 방안 & 개도국 인적자원개발지원 모델 설정 \\
\hline 개도국 고용 · 노동 정책분야 ODA 확대 방안 & $\begin{array}{l}\text { OECD DAC 회원국의 노동환경, 고용안정 } \\
\text { 부문 지원 사례와 유형화 }\end{array}$ \\
\hline 개도국 현금이전프로그램 개선 방안 & $\begin{array}{l}\text { 생산적 안전망 프로그램(PSNP)과 현금지원 } \\
\text { 프로그램의 재구성 가능성/ 현장 지향적인 } \\
\text { 모델 구상 }\end{array}$ \\
\hline
\end{tabular}

출처: 저자 작성

결국 개도국 빈곤해소 및 재빈곤화 방지 정책과 공정한 사회적 기회 제공 및 안전망 확대 차 원에서 '일자리 창출 사업' 과 '기업의 사회적 책임(CSR)' 을 연계할 필요성이 있다. 사회적 일 자리(사회적 서비스) 확대는 한 국가의 사회적 경제(Social Economy) 영역의 확대를 가져오며 이는 취업계층의 빈곤탈출 가능성을 높임과 동시에 빈곤에 대한 안전망(재빈곤화의 위험성 방 지)을 제공할 수 있다고 판단된다. 이 연구의 주요 목적은 첫째, 개도국 사회적 일자리 창출 사 업이, 특히 사회취약계층에게 '자력구제 안전망' 을 제공하는 효과를 가질 수 있는지에 대해 사 
례 연구를 통해 사업모델을 제시하고자 하며, 둘째, 개도국의 사회적 일자리가 '차별성' 과 '전 문성' 을 담보하는 양질의 일자리 창출로 이어질 가능성에 대한 검증 이다. UNDP는 2009년 보 고서 'Green Jobs for the Poor' 를 통해 환경적 관점에서 개도국의 새로운 일자리 창출 가능 성을 남아프리카 공화국의 수자원 산업과 인도의 지역 고용안정 프로그램 사례연구를 통해 점 검한다. 또한 이를 통해 ‘환경적인 공적고용프로그램(environmental public employment programme) '의 가능성과 그 범위7), 그리고 관련 재정조달 방식을 제안한다(Lieuw-KieSong, 2009). 또한 UNDP는 2008년 보고서 '사회적 기업 (Social Enterprise)'을 통해 빈곤 감소와 고용 형성의 새로운 대안 모델로 사회적 기업을 언급했다(Borzaga and Galera, 2008). 이 보고서에서 유럽의 사회적 기업 경험과 모델이 개도국 지역 커뮤니티의 활성화, 빈곤 의 효과적이고도 혁신적인 감소에 큰 시사점을 줄 수 있다고 판단하고 있다. 실제로 폴란드, 우 크라이나, 세르비아의 사례연구를 통해 해당 국가의 사회적 기회, 안전망 구축에 사회적 기업이 매우 긍정적인 역할을 하고 있음을 주목하고 있다.

한편 이러한 맥락에서 개도국 안전망 관련 'workfare 프로그램' 에 주목할 필요가 있다. workfare는 일(work)과 복지(welfare)의 합성어로 '일하는 사람을 위한 복지' 를 의미한다. 이 개념은 영국이 1970년대 말 이후 국제통화기금(IMF)의 구제 금융을 받으면서 경제적 위기를 타개해 나가기 위해 도입한 개념으로, '일하는 것을 조건' 으로 공적인 부조를 베푸는 것을 말한 다. 즉, 무조건적인 사회안전망 제공이 오히려 노동 의욕을 떨어뜨릴 수 있다는 비판에 대한 정 책적 산물로, 예를들어 직업을 잃은 근로자는 실업수당을 수령하기 위해서 자발적이고도 적극 적인 구직 활동을 해야 한다. 이러한 맥락에서 사회적 기회와 안전망을 동시에 충족시키는 개념 으로 평가 받는다.

둘째, 개발협력에서의 민간부문 활성화 방안 연구이다. 이 연구는 개도국 사회적 기회 · 안전 망 확대를 위한 공공-민간 파트너십(PPP) 구축을 중심으로 이루어질 수 있다. 연구 배경은 첫 째, 개도국 민간부문 활성화는 소득수준 향상, 고용창출, 역량개발, 조세 수입 증가를 가져오며, 따라서 개도국 지속가능한 발전에 필수 요소라는 판단과, 둘째, 효과적인 공공-민간 파트너십 (PPP) 구축은, (1) 개발재원 확대 (2) 위험부담 분담 (3) 민간부문의 전문성과 창의성 활용 (4) 재 정지출의 합리화 및 효율화, 사업관리 및 감독 개선 측면에서 $\mathrm{ODA}$ 사업의 효과성을 제고하며, 개도국의 사회적 기회 - 안전망 확대에 기여한다고 평가받고 있다는 데 있다. 또한 UNDP의 '공공 - 민간 파트너십 프로그램에 기초한 빈곤층을 위한 사업 창출 보고서' 도 이러한 개도국

7) 이 범위에는 토양오염 방지, 수중 작물재배, 재활용 산업, 태양 에너지 등 환경 에너지 사업, 화재 예방산업, 친환 경적 난방 시스템, 녹화 조림사업 등이 해당된다. 
민간부문의 빈곤퇴치와 지역사회 공동가치 창출에 대한 기여를 언급하고 있다. 따라서, 본 연구는 효과적인 공공-민간 파트너십 구축과 개도국 민간부문 활성화가 개도국의 교육, 의료 - 보건, 빈곤문제 분야의 사회적 기회 · 안전망 확대에 기여하는 과정을 사례를 통해 분석하고 바람직한 협력방안을 제시할 수 있을 것이다. 연구의 주요 대상과 목표는 첫째, 개발협력에서 공공-민간 파트너십 구축 성공사례 발굴 및 모델링 둘째, 개도국 사회적 기회 - 안전망 확대를 위한 성공적 인 민간부문 비즈니스와 가치사슬(Value Chain)형성 사례 분석 그리고 이를 통해 셋째, 한국 의 개발협력 과정에 적용 가능한 공공-민간 파트너십 모델 제시 등이다.

셋째, 수원국 중심 인적자원(human resource) 개발 지원 방안에 대한 연구가 필요하다. 이 는 직업훈련 제도의 지원, 정착을 염두에 둔 연구 영역으로, 특히 인적자본축적 전략과 이를 통 한 '생산적 일자리' 창출 방안과 맞물려 있다. 교육훈련분야, 특히 직업훈련 분야의 유럽 선진 국의 발전 경험은 개도국에 큰 지향점을 제공해 줄 수 있음은 자명하다. 하지만 개도국 인적자 원개발은 선진 공여국의 모델 지시적인 전략보다 수원국 현장 지향적(Local Oriented)인 모델 개발 전략 모색이 필수이다. 즉, 환경조성·사회적 전환(enabling environment· social transformation) 전략이 필요하다. 결국 선진공여국의 직업교육 분야 노하우와 지원이 어떻게 개도국 현장 요구와 적절히 조화될 수 있는가에 대한 연구이다. 이 분야는 상대적으로 활발히 연구, 보고되고 있는 영역이다8). 보다 구체적인 선진공여국의 적용 사례연구, 예를 들어 독일 GIZ(Deutsche Gesellschaft fuer internationale Zusammenarbeit)의 국별 차원 지원 전 략 사례9)를 살펴봄은 개도국 인적자원개발지원 모델 설정에 보다 유용한 시사점을 제공할 수 있다. 또한 선진 공여국의 개도국 정보통신기술(ICT) 인력 개발 지원 사업에 대한 현황 분석과 연구도 수원국 중심 인적 자원 개발을 위한 기반이 될 수 있다.

넷째, 개도국 고용, 노동 정책분야 ODA 확대 방안 연구이다. 글로벌 경제 위기 이후 전 세계 의 화두는 고용창출이며 개도국 또한 노동환경의 개선, 일자리 창출, 고용안정 등 고용·노동 분야 인프라 구축을 통한 빈곤감축을 가장 중요한 정책 목표로 삼고 있다. 예를 들어 베트남, 캄 보디아, 라오스, 인도네시아 등 ASEAN 주요 개도국은 빈곤감축전략(PRS)에서 고용창출 및 노 동기회 확대 등을 통한 빈곤감축을 우선 이행목표로 삼고 있다.

8) 직업훈련 분야는 2010년 5월 수립된 KOICA 선진화 계획과 연계하여 교육부문 중점 사업 분야로 선정되었으며 관련하여 수행된 “직업훈련 개발협력 프로그램 모델연구"를 참조할 수 있다.

9) 독일의 개도국 지원 정책의 중점 영역은 직업훈련시스템구축, 고용센터 건립, 교사 숙련도와 전문성 향상 프로그 램 설정, 비정규직(실업자) 고용안정(재취업)을 위한 훈련 프로그램 제공 등이다. 
이 부문에 관심을 가질 수 있는 근거는, 빈곤은 고용·노동정책과 관련이 있다는 점인데, 즉 개도국의 고용 - 노동시장 정책은 그 나라의 빈곤 감소와 중, 장기적으로 직접적이고도 긴밀한 관련을 가지고 있기 때문이다. 주요 연구내용은 $\mathrm{OECD} \mathrm{DAC를} \mathrm{중심으로} \mathrm{한} \mathrm{선진} \mathrm{공여국,} \mathrm{특히}$ 미국과 독일의 개도국 고용 - 노동 분야 ODA 지원 프로그램과 사례를 연구하고 이를 유형화하 는 것이며, 연구영역은 크게, $\mathrm{DAC}$ 회원국의 (1) 노동환경 부문(근로시간, 임금체계, 작업환경, 노동복지 등) 정책 지원 사례 (2) 고용안정 부문(취업센터 운영 프로그램 등) 지원 사례 로 구분 할 수 있다. 또한 이를 통해 한국의 개도국 고용 - 노동정책 분야 $\mathrm{ODA}$ 사업 추진의 필요성과 가 능성 제시할 수 있다.

이에 대한 연구는 ILO와 UNDP 등에서 수행되어 오고 있는데, Osmani(2002)는 ILO와 UNDP 공동 연구를 통해 '괜찮은 일자리(decent work)' 와 빈곤감소간의 상관관계를 경험적 분석을 통해 밝히려고 시도했다. 연구를 통해 결국 '괜찮은 일자리' 가 인적개발과 빈곤 감소 측 면, 즉 사회적 기회와 안전망 측면 모두에 긍정적인 영향을 미친다는 점을 강조했다. 국내에서 는 한국노동연구원(KLI)와 노사발전재단 $(\mathrm{KILF})$ 국제노동협력센터 등에서 관련 연구 주제가 제 기되고 있다.

다섯째, 개도국 현금지원프로그램(Cash Transfer Program) 개선 방안 연구이다. 이는 그간 남미와 아프리카 지역에서 수행된 프로그램의 성과를 생산적 안전망 프로그램 (Productive Safety Net Program; PSNP)과 연계시키는 방안을 중심으로 이뤼질 수 있다. 연구의 배경은, 첫째, 사회적 보호(Social Protection)의 한 형태로 주목 받는 현금지원프로그램(Cash Transfer Program, CTP)은 '개도국의 빈곤을 줄이면서 동시에 소득분배 구조를 개선하는 효 과를 가진다고 평가되고, 둘째, 현금지원프로그램의 기본 문제의식은, 빈곤층에게 가장 필요한 것 중의 하나가 ‘현금' 이며, 이 돈의 사용방법 또한 해당 빈곤층이 가장 잘 알고 있다는 점에서 출발 한다. 현금지원프로그램은 근로와 교육 등을 조건으로 하는 (1) 조건부 현금지원 (Conditional Cash Transfer: CCT), (2) 조건 없는 현금지원, (3) 사회취약계층대상 현금지원, (4) 식량구호를 대체하는 현금지원 프로그램 등으로 나누어진다. 조건부현금지원 프로그램의 대 표적인 형태로는 2006년 세계은행 인간개발포럼에서 소개된 '가족지원금(Bolsa Familia)' 과 칠레의 '경제사회안정기금(Economic and Social Stabilization Fund)', 멕시코의 '오포르투 니다데스(Oportunidades)' 등을 들 수 있는데, 이는 교육, 보건, 고용창출 등 '사회안전망 구 축을 종합적으로 고려한 빈곤퇴치 프로그램' 으로 주목 받았다. 한편 식량구호를 대체하는 현금 지원 프로그램은, 2005-2006년 식량위기를 계기로 우간다, 말라위, 에티오피아 등 아프리카 지역에서 실행되었던 현금지원 프로그램을 들 수 있다.

그런데, 조건부현금지원 프로그램의 단기적 효과, 지역적 차이를 고려하지 않은 일괄적 지원 
의 실패 등, 그간 시도된 현금이전 프로그램의 한계 또한 드러나고 있다. 따라서 '생산적 안전망 프로그램 (Productive Safety Net Program; PSNP)10)' 이라는 보다 포괄적인 사회안전망 틀에서 그간의 성과를 평가하고 이를 바탕으로 프로그램의 재구성이 필요한 시점이라 하겠다. 정리하자면, 연구는 (1) 그간 수행된 현금지원프로그램의 동향을 파악하고, (2) 생산적 안전망 프 로그램(PSNP) 틀에서 현금지원 프로그램의 재구성 가능성을 모색하며, (3) 이를 통해, 개도국 재빈곤화 방지와 취약계층 사회적 기회 제공 측면에서 보다 현장 지향적인 모델 제안을 할 수 있다. 주요 연구 내용은, 첫째, 남미, 아프리카 등지에서 수행되었던 다양한 현금지원프로그램 (CTP)의 동향 파악과 유형화(장점과 한계를 분석, 이를 통한 모델링), 둘째, 현금지원프로그램 을 생산적 안전망 프로그램(PSNP)의 틀에서 실행, 평가한 사례 분석, 예를 들어, 개도국의 만 성적 식량위기의 원인을 생산적 안전망 프로그램 틀로 진단하고 현장에 맞는 현금지원 프로그 램을 적용한 사례와 이를 통한 현금지원 프로그램의 개선 가능성 모색, 셋째, 위 연구를 통해 국 내 ODA 부문에서 실현가능한 현금지원프로그램 사업유형 발굴 등이다.

10) 생산적 안전망 프로그램(PSNP): 빈민층을 구호의 대상이 아닌 사회적으로 보호받을 권리가 있는 시민으로 보는 관점 하에 이들에게 사회보호를 보장함으로써 빈곤층 스스로가 주체적으로 빈곤감소를 할 수 있도록 지원하는 프로그램 


\section{참고문헌}

\section{1. 국내문헌}

고세훈(2011), ‘복지국가와 공적개발원조: 국제협력을 위한 국내적 토대의 중요성' , 『국제개발 협력』, 2011년 제2호, KOICA

김성규(2011), ‘사회적 기업 연구 동향과 주요 이슈' 『사회적 기업과 인적자원 전략』, KLI 연 구보고서, 한국노동연구원

김성규(2012), 기업의 글로벌 사회적 책임(Global CSR)과 개발협력, 『국제개발협력』, 2012년 제 1 호, $\mathrm{KOICA}$

김승택(2001), 사회안전망 체계의 국제비교 연구( I ): 영국, 한국노동연구원

김장기(2009), 국가 사회안전망 정책의 탐색: 통합적 관점을 중심으로, 한국공공관리학보, 제 23권, 제4호, pp. 211-230.

박양근, 신소영(2000), 사회안전망으로서 실업자 직업훈련 내실화 방안, 직업능력개발연구, 제 3권.

박원후(2000), 사회통합을 위한 사회안전망 구축, 보건복지포럼, 2000년 1호, pp.16-24.

방하남, 유길상, 안학순(1998), 실업과 사회안전망, 한국사회복지정책, 제7집, pp.267-291

윤순진(2006), 사회적일자리를 통한 환경, 복지, 고용의 연결, $\mathrm{ECO} 2006$,

제 10 권, 제 2 호.

이장원(2007), 기업의 사회적 책임(CSR)의 노동관련 국제동향과 시사점, 노동리뷰 통권 제32 호, pp.35-47, 한국노동연구원

정무성(2006), 양극화 문제 해소를 위한 사회안전망 구축방안, 사회과학논총, 제8집.

정형선(1998), OECD 국가의 사회안전망, 보건복지포럼, 98년 10호, pp.49-71.

조정현(2011), 사회안전망 확충을 위한 개발 원조 방향, 『국제개발협력』, 2011년 제2호, KOICA.

황덕순(2011), 개발도상국의 사회안전망 강화를 위한 개발협력과 한국의 역할, 『국제개발협력』, 2011년 제2호, KOICA. 


\section{2. 국외문헌}

Bhattacharya, C.B.,(2008), 'Using Corporate Social Responsibility to Win the War for Talent', MIT Sloan Management Review, vol.49, no.2.

Borzaga, Carlo and Galera, Giulia ed.(2008), Social Enterprise: A new model for poverty reduction and employment generation: An examination of the concept and practice in Europe and the Commonwealth of Independent States, UNDP.

Carroll, Kate(2011), "The Case for Social Protection within a National Development Strategy Framework". International Conference: Social Protection for Social Justice. Institute of Development Studies.

Grosh, Margaret and Ninno, Carlo et. al. (2008), For Protection and Promotion: The Design and Implementation of Effective Safety Net, The World Bank, Washington, D. C.

Hagemejer, Krzysztof(2009), 'Can Low-Income Countries Afford Basic Social Security? in Promoting Pro-Poor Growth: Social Protection, OECD.

Hopkins, Michael(2008), Corporate and Stakeholder Responsibility: Theory and Practice, Fifth Annual Forum on Business Ethics and Corporate Social Responsibility in a Global Economy, Milan, 22th-23th May 2008.

ILO/UNDP(2011), Successful Social Protection Floor Experiences, Sharing Innovative Experiences Series Vol. 18.

Kahn, Azizur Rahman(2005), Growth, Employment and Poverty: An Analysis of the vital Nexus based on some Recent UNDP and ILO/SIDA Studies, Paper prepared under the joint ILO-UNDP programme on Promoting Employment for Poverty Reduction, UNDP, New York, ILO, Geneva.

Korachun, D., Bhattacharya, C. B. and Swain, S.,(2011), 'When and How Does Corproate Social Responsibility Encourage Customer Orientation?, Working Paper.

Kotler, Philip and Lee, Nancy(2004), Corporate Social Responsibility: Doing the Most Good for Your Company and Your Cause, Wiley.

Kulke, Ursula(2009), The ILO Campaign for Basic Social Protection: Right to Social Security in Development International Symposium, Berlin, 10-20 Oct. 2009.

Lieuw-Kie-Song, Maikel R.(2009), Green Jobs for the Poor: a Public Employment approach, Discussion Paper, April 2009, UNDP. 
Luis Frota(2007), Campaign on the extension of Social Security for all, STEP Programme ILO Social Security Department.

Osmani, S.R.(2002), Exploring the Employment Nexus: Topics in Employment and Poverty, A report for the Task Force on the Joint ILO-UNDP Programme on Employment and Poverty, UNDP, New York, ILO, Geneva.

OECD(2009), Promoting Pro-Poor Growth: Social Protection, OECD.

OECD(2001), The DAC Guidelines Poverty Reduction, OECD.

OECD(2001), The DAC Guidelines Strategies for Sustainable Development: Guidance for Development Co-operation, OECD.

OECD(2003, 2007, 2009, 2011), Development Co-operation Report, OECD

Ofreneo, Rosalinda P.(2011), “The Rights-Based People’ s Social Protection Agenda: interweaving Social, Gender and Environmental Justice”, International Conference: Social Protection for Social Justice, Institute of Development Studies.

Pava, MI., Krausz, J.,(1996), 'Corporate Social Responsibility and Financial Performance: the paradox of social cost', Westport, Quorum Books.

Poter, Michael E. and Kramer, Mark R.(2006),' Strategy \& Society : The Link Between Competitive Advantage and Corporate Social Responsibility', Harvard Business Review, vol.84, no.12.

Stanwick, P. A. and Stanwick, S. D., (1998), "The relationship between corporate social performance and organizational size financial performance and environmental performance: an empirical examination', Journal of Business Ethics, vol. 17.

UN(2001), Strengthening Policies and Programmes on Social Safety Nets: Issues, Recommendations and Selected Studies, Economic and Social Commission for Asia and the Pacific, UN Publications.

UNDP, ILO and Global South-South Development Academy(2011), Sharing Innovative Experiences: Successful Social Protection Floor Experiences Vol. 18, UNDP.

Yi, Ilcheong(2010), Social Protection, Social Security and Social Service in a Development Context: Transformative Social Policy Approach, Journal of International Development Cooperation, 2010 No.4, KOICA. 